Article

\title{
Humidity Driven Transition from Insulator to Ionic Conductor in Portland Cement
}

\author{
Masahiro Nagao, Kazuyo Kobayashi, Tetsuya Hori, Yaorong Li and Takashi Hibino * \\ Graduate School of Environmental Studies, Nagoya University, Nagoya 464-8601, Japan; \\ nagao@urban.env.nagoya-u.ac.jp (M.N.); kkoba@urban.env.nagoya-u.ac.jp (K.K.); \\ tetsuya.hori.j6b@soken-labs.co.jp (T.H.); tmhibino@watch.ocn.ne.jp (Y.L.) \\ * Correspondence: hibino@urban.env.nagoya-u.ac.jp; Tel.: +81-52-789-4888
}

Received: 16 October 2019; Accepted: 8 November 2019; Published: 9 November 2019

\begin{abstract}
This work aims to assess ionic conduction in anhydrous cement particles and hydrated cement pastes with aging periods of 5-25 days. When a cement sample was humidified (relative humidity $=100 \%$ ) over the range of $50-100{ }^{\circ} \mathrm{C}$, it exhibited bulk conductivities of $10^{-3}-10^{-2} \mathrm{~S} \mathrm{~cm}^{-1}$, regardless of the hydration level, whereas the interfacial conductivities varied in the range of $10^{-7}-10^{-3} \mathrm{~S} \mathrm{~cm}^{-1}$, depending on the structural defects or conduction pathways of the sample. Both the bulk and interfacial conductivities were increased to $0.01 \mathrm{~S} \mathrm{~cm}^{-1}$ or higher at $100^{\circ} \mathrm{C}$, although the sample required previous moistening with water mist. The major charge carrier in the sample was determined to be hydroxide ions, and the total ion transport number was approximately 1. Exposing the sample to a mixture of carbon dioxide and water vapor caused a decrease in the bulk and interfacial conductivities; however, the bulk conductivity was returned to the initial value by treatment with an acid.
\end{abstract}

Keywords: Portland cement; ionic conduction; hydroxide ion; $\mathrm{CO}_{2}$ exposure

\section{Introduction}

Portland cement is the most commonly used binder in the construction industry. The major components of Portland cement are tricalcium silicate $\left((\mathrm{CaO})_{3} \cdot \mathrm{SiO}_{2} ; \mathrm{C}_{3} \mathrm{~S}\right)$, dicalcium silicate $\left((\mathrm{CaO})_{2} \cdot \mathrm{SiO}_{2} ; \mathrm{C}_{2} \mathrm{~S}\right)$, tricalcium aluminate $\left((\mathrm{CaO})_{3} \cdot \mathrm{Al}_{2} \mathrm{O}_{3} ; \mathrm{C}_{3} \mathrm{~A}\right)$, and tetracalcium aluminoferrite $\left((\mathrm{CaO})_{4} \cdot \mathrm{Al}_{2} \mathrm{O}_{3} \cdot \mathrm{Fe}_{2} \mathrm{O}_{3} ; \mathrm{C}_{4} \mathrm{AF}\right)[1,2] \cdot \mathrm{C}_{3} \mathrm{~S}$ and $\mathrm{C}_{2} \mathrm{~S}$ react with water to form the corresponding calcium silicate hydrates (C-S-H) and calcium hydroxide $\left(\mathrm{Ca}(\mathrm{OH})_{2}\right)[3,4]$. These hydration reactions proceed from the surface into the center of the cement particles. The hydration rate of $C_{3} S$ is faster than that of $\mathrm{C}_{2} \mathrm{~S}$ due to its higher reactivity for hydration [5]. $\mathrm{C}_{3} \mathrm{~A}$ and $\mathrm{C}_{4} \mathrm{AF}$ also undergo hydration, but have not been considered to produce any $\mathrm{Ca}(\mathrm{OH})_{2}$ until recently [6,7]. Similar to sodium hydroxide $(\mathrm{NaOH})$ and potassium hydroxide $(\mathrm{KOH})$ present in the hydrated cement paste, the produced $\mathrm{Ca}(\mathrm{OH})_{2}$ results in a $\mathrm{pH}$ level (11-13) in the cement paste, until these metal hydroxides are depleted by carbonation with carbon dioxide $\left(\mathrm{CO}_{2}\right)$ that penetrates from the atmosphere [8,9].

Such alkaline characteristics have been mainly studied to elucidation of the mechanism for the formation of C-S-H [10-13]. Nevertheless, there have been few reports on ionic conduction associated with the alkalinity of Portland cement, although there was a report that describes the conduction of potassium ions in the commercial geopolymer cement known as geocement [14]. So far, electrochemical impedance spectroscopy (EIS) has been limited to assessment of the dielectric properties, mechanical strength, carbonation, and chlorination behaviors of concrete, mortar, and cement paste [15-18]. This is because the electrical resistance of hardened Portland cement pastes is too high when measured with a thick test sample under dry conditions at room temperature. In the case of solid acids (e.g., Nafion and inorganic materials), resistance measurements are typically conducted with a thin film or membrane 
sample in an atmosphere saturated with water vapor (relative humidity $=100 \%$ ) over the temperature range from room temperature to $100^{\circ} \mathrm{C}$ [19-21]. Operation at high humidity and temperature further enhances the proton conductivity of the solid acids [22,23]. A similar approach could be an effective technique for the measurement of cement particles and hydrated cement pastes. Data from EIS measurements, combined with X-ray crystallography and electron microscopy, would also enable postulation of the ionic conduction mechanisms in the bulk and interfacial phases of cement.

Anion exchange membranes are regarded as promising electrolytes for fuel cell and electrolysis applications in alkaline media [24-26]; however, their main chain and functional groups are easily degraded by an attack from hydroxide ions $\left(\mathrm{OH}^{-}\right)$, especially at high $\mathrm{pH}$ and temperature [27-30]. If cement particles or paste exhibit high hydroxide ion conductivity, this material could be an alternative electrolyte to anion exchange membranes because of their high stability under conditions of high $\mathrm{pH}$ and temperature. In this study, we assessed the ion conducting properties of three cement samples with different degrees of hydration using the same approaches as that for the measurement of solid acids. The main contents of this work are as follows. The origin of ionic conduction associated with $\mathrm{Ca}(\mathrm{OH})_{2}$ was independently evaluated just after production and after 5 days or more. The charge carrier in the cement was determined from the element analysis at the anode and cathode sides after direct current (DC) polarization. The ion transport number of the cement was estimated by the gas concentration cell method. Finally, the effect of $\mathrm{CO}_{2}$ in the atmosphere on the ionic conductivity was investigated, along with the recovery of carbonated cement.

\section{Materials and Methods}

\subsection{Materials}

The Portland cement used in this work was purchased from Taiheiyo Cement Corporation (Tokyo, Japan). Hydration of the cement was performed by the addition of deionized water to obtain a water to cement weight ratio (W/C) of 5:15, which gives a good balance between the strength and porosity [31]. The degree of hydration was adjusted by control of the mixing time from 5 to 25 days in a ball mill (P-5, Fritsch, Idar-Oberstein, Germany). The powder $(0.200 \mathrm{~g})$ of the anhydrous or hydrated cement was mixed with polytetrafluoroethylene (PTFE) powder $(0.013 \mathrm{~g})$ using a mortar and pestle, and then cold-rolled to a thickness of $300 \mu \mathrm{m}$ and a diameter of $17 \mathrm{~mm}$ using a laboratory rolling mill. A hardened hydrated cement paste cube $(10 \mathrm{~mm} \times 10 \mathrm{~mm} \times 0.5 \mathrm{~mm})$ was also prepared with the same $\mathrm{W} / \mathrm{C}$ for comparison. The thickness of $0.5 \mathrm{~mm}$ was obtained by polishing the sample surface with 100and 200-grit SiC abrasive papers (Sankyo Rikagaku, Saitama, Japan). A Pt/C electrode (Electrochem, Woburn, MA, USA, Pt loading: $2 \mathrm{mg} \mathrm{cm}^{-2}$ ) was used as the electrode for all trials. High purity Ar, air, and $\mathrm{CO}_{2}$ were obtained from Taiyo Nippon Sanso (Japan) and high purity $\mathrm{H}_{2}$ was obtained from GL Science (Japan). Various mixtures of $\mathrm{Ar}$ and air, $\mathrm{H}_{2}$, or $\mathrm{CO}_{2}$ were produced using a mass flow controller (MGL-2, GL Science, Tokyo, Japan). Acetic acid (Wako Chemicals, Osaka, Japan) was used without further purification.

\subsection{Characterization}

The crystalline structures of the cement samples were analyzed using X-ray diffraction (XRD; Bruker D8 Advance, Bruker AXS, Karlsruhe, Germany) with Cu K $\alpha$ radiation $(\lambda=1.5418 \AA)$ as the $X$-ray source. The diffractometer was operated at $40 \mathrm{kV}$ and $40 \mathrm{~mA}$. Rietveld refinement of the sample was performed using the Bruker AXS's Topas 3.0 software. Compositional mappings of the cement samples were acquired in combination with the morphological features using energy dispersive X-ray (EDX) spectroscopy and scanning electron microscopy (SEM; Jeol JSM-6610A, Tokyo, Japan) with acceleration voltages of 15 and $2 \mathrm{kV}$, respectively. Preparation of cross-sectional cement samples was performed using a beam of accelerated Ar ions rather than water to avoid damage during the cutting and polishing processes. The degree of hydration for the cement samples was calculated from the amount of chemically bound water in the paste, which was measured as the difference in 
weight between the samples after drying at 105 and $1000{ }^{\circ} \mathrm{C}$, as described elsewhere [32]. The weight measurements were done using thermogravimetry (TG; Shimadze TGD-60, Kyoto, Japan). The $\mathrm{pH}$ of the cement sample immediately after humidification was determined using broad range $\mathrm{pH}$ paper (PEHANON, Macherey-Nagel, Düren, Germany). A sealed container containing sodium hydroxide particles was used to dry the cement samples with the temperature maintained at $50^{\circ} \mathrm{C}$.

\subsection{Electrochemical Measurements}

EIS measurements of the cement samples were performed using the four probe method. A cement sample was sandwiched between two Pt/C electrodes (effective area: $0.5 \mathrm{~cm}^{2}$ ) and then set in a flow of Ar saturated with water vapor (relative humidity $=100 \%$ ) at temperatures between 50 and $100{ }^{\circ} \mathrm{C}$, unless otherwise stated. Impedance spectra were collected at open-circuit voltage with an amplitude of $60 \mathrm{mV}$ over the frequency range of $1-10^{6} \mathrm{~Hz}$. An equivalent circuit model was used for fitting of the impedance data. DC polarization was conducted with a current density of $0.4 \mathrm{~mA} \mathrm{~cm}^{-2}$ in a flow of humidified air at $70^{\circ} \mathrm{C}$. The following gas concentration cells were fabricated using cement samples as the electrolyte with two $\mathrm{Pt} / \mathrm{C}$ electrodes: air $+\mathrm{Ar}(0.31 \mathrm{~atm}$ water vapor), $\mathrm{Pt} / \mathrm{C} \mid$ electrolyte $\mid \mathrm{Pt} / \mathrm{C}$, air (0.31 atm water vapor), and $\mathrm{H}_{2}\left(0.31 \mathrm{~atm}\right.$ water vapor) $\mathrm{Pt} / \mathrm{C} \mid$ electrolyte $\mid \mathrm{Pt} / \mathrm{C}, \mathrm{H}_{2}+\mathrm{Ar}(0.31 \mathrm{~atm}$ water vapor) $[33,34]$. The electromotive force (EMF) of the galvanic cells was recorded at $70{ }^{\circ} \mathrm{C}$. All measurements were conducted using a potentio-galvanostat (Solartron 1287, UK) and a frequency response analyzer (Solartron 1260, Hampshire, UK).

\section{Results and Discussion}

\subsection{Ionic Conductivity of Portland Cements with Different Degrees of Hydration}

First, the electrical resistance of the anhydrous cement sample was measured to clarify whether the cement particles become ionically conductive only by humidification. The impedance spectra recorded at $50{ }^{\circ} \mathrm{C}$ are shown in Figure $1 \mathrm{a}$, in which the partial pressure of water vapor $\left(P_{\mathrm{H} 2 \mathrm{O}}\right)$ in the atmosphere was $0.03 \mathrm{~atm}$ at zero minutes and subsequently $0.12 \mathrm{~atm}$. All the obtained spectra showed intercepts of the impedance lines and the real axis, circular arcs above the real axis, and inclined lines. These lines were fitted with an equivalent circuit consisting of three impedance components in series: the serial resistance, the parallel resistance, the constant phase element (CPE), and the Warburg impedance element. The serial resistance is related to short-range ion transport $[35,36]$, which was assigned to the bulk resistance of the sample. The non-capacitive behavior is due to reversible ion transport on the surface of the cement particles. The parallel resistance is related to long-range ion transport $[35,36]$; however, it is not evident whether this is dominated by a grain boundary- or pore-related mechanism. This interfacial resistance component is dependent on the morphology of the cement (e.g., particle size and structural defects) [37], as will be discussed later. Figure $1 \mathrm{~b}$ shows plots of the bulk and interfacial resistances computed from the equivalent circuit against the time after switching $P_{\mathrm{H} 2 \mathrm{O}}$. The two resistances at zero minutes were obtained after previously aging at $P_{\mathrm{H} 2 \mathrm{O}}=0.03 \mathrm{~atm}$ and $50{ }^{\circ} \mathrm{C}$ (exactly speaking, the sample was already hydrated at this stage). When $P_{\mathrm{H} 2 \mathrm{O}}$ was switched to $0.12 \mathrm{~atm}$, the two resistances rapidly decreased with time and became almost constant at $30 \mathrm{~min}$, which indicates a large contribution from ionic conduction associated with water vapor to the electrical characteristics of the cement particles.

After the impedance measurements, the cement sample was dried in a sealed container with sodium hydroxide particles. The XRD pattern of this sample was compared with that of the anhydrous cement sample, and the result is shown in Figure 1c. No significant difference in peak intensity was apparent between the two samples, except that the diffraction peaks due to gypsum disappeared after the impedance measurement (the virgin cement particles contain small amounts of $\mathrm{CaSO}_{4} \cdot 2 \mathrm{H}_{2} \mathrm{O}$ and alkaline metal oxides $\left(\mathrm{Na}_{2} \mathrm{O}\right.$ and $\left.\mathrm{K}_{2} \mathrm{O}\right)$ [38]). No detectable level of crystalline $\mathrm{Ca}(\mathrm{OH})_{2}$ was generated in the cement after humidification and then drying. To understand the significant decrease in electrical resistance by the increase in $P_{\mathrm{H} 2 \mathrm{O}}$ observed in Figure $1 \mathrm{a}, \mathrm{b}$, the basicity of the cement sample 
immediately after humidification was inspected with a $\mathrm{pH}$ indicator strip. The strip was colored between pink and purple by contact with a small amount of water remaining on the sample surface, which indicated a $\mathrm{pH}$ of 11-12, and thus, the presence of $\mathrm{OH}^{-}$ions on the surface of the sample just after humidification.

(a)

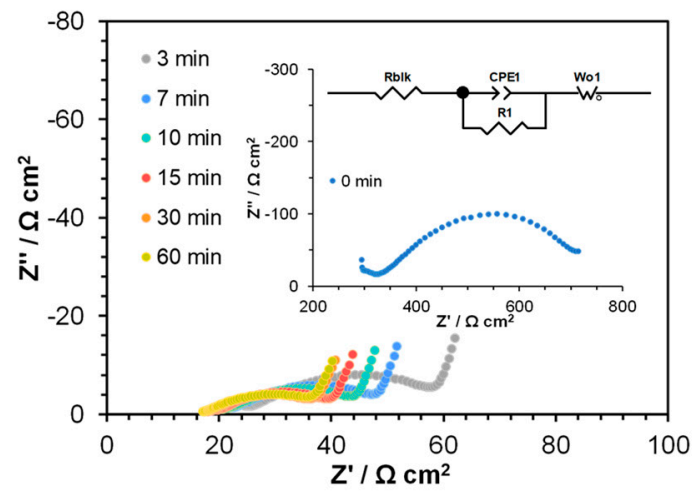

(b)

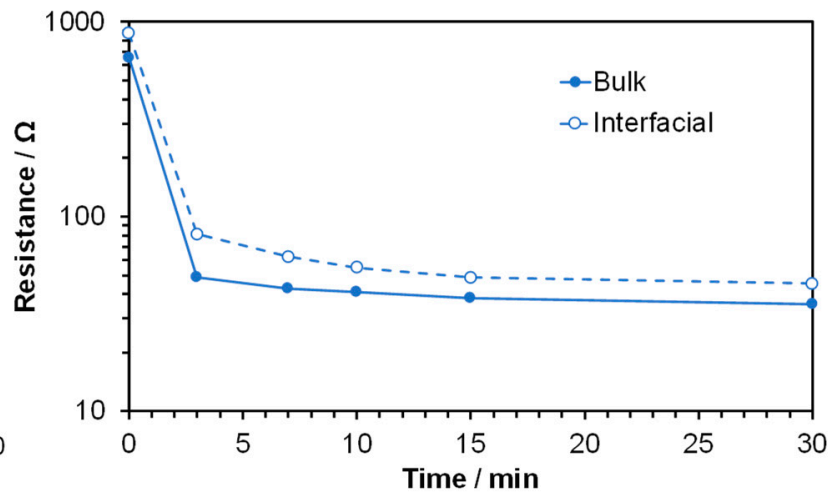

(c)

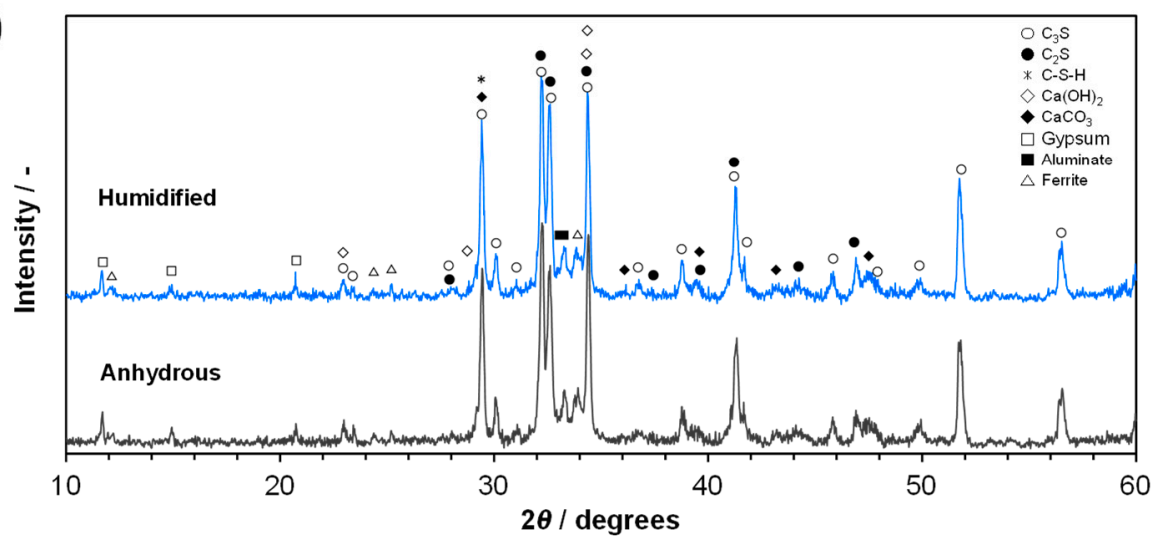

Figure 1. Characterization of the cement sample humidified in an atmosphere saturated with water vapor at $50{ }^{\circ} \mathrm{C}$. (a) Impedance spectra recorded at various times after switching $P_{\mathrm{H} 2 \mathrm{O}}$ from 0.03 to $0.12 \mathrm{~atm}$. The inset shows the equivalent circuit model used to fit the impedance data. (b) Bulk and interfacial resistances computed from the equivalent circuit as a function of the time after switching $P_{\mathrm{H} 2 \mathrm{O}} \cdot(\mathbf{c}) \mathrm{XRD}$ patterns before and after humidification and drying.

The cement hydration process consists of complicated chemical reactions. First, the alkaline metal oxides are hydrated to form the corresponding metal hydroxides $(\mathrm{NaOH}$ and $\mathrm{KOH})$. At the next stage, oxygen ions $\left(\mathrm{O}^{2-}\right)$ of the $\mathrm{CaO}$ lattice in $\mathrm{C}_{3} \mathrm{~S}$ react with protons $\left(\mathrm{H}^{+}\right)$in water molecules to form $\mathrm{OH}^{-}$ ions according to Reaction (1). The two $\mathrm{OH}^{-}$ions combine with a calcium ion $\left(\mathrm{Ca}^{2+}\right)$ of the $\mathrm{CaO}$ lattice to form $\mathrm{Ca}(\mathrm{OH})_{2}$ according to Reaction (2) [39].

$$
\begin{gathered}
\mathrm{O}^{2-} \text { (lattice) }+\mathrm{H}^{+}(\mathrm{aq}) \rightarrow \mathrm{OH}^{-}(\mathrm{aq}) . \\
2 \mathrm{OH}^{-}(\mathrm{aq})+\mathrm{Ca}^{2+}(\mathrm{aq}) \rightleftarrows \mathrm{Ca}(\mathrm{OH})_{2} \text { (solid). }
\end{gathered}
$$

These rapid reactions proceed for a few hours in what is called a pre-induction process [40]. It is thus assumed that the decrease in the electrical resistance of the cement sample by humidification is due to the formation of $\mathrm{OH}^{-}, \mathrm{Na}^{+}, \mathrm{K}^{+}$, and $\mathrm{Ca}^{2+}$ ions. In addition, conduction pathways are established by water channels on the surface of $\mathrm{C}_{3} \mathrm{~S}$ particles or the pore wall of $\mathrm{C}-\mathrm{S}-\mathrm{H}$, in which the produced ions migrate, probably via the vehicular diffusion mechanism [41-43].

Ionic conduction in two paste samples with different degrees of hydration (0.33 and 0.99) was investigated next. XRD patterns of these paste samples are provided in Figure 2a, including that of 
the anhydrous sample for comparison. Although peaks that correspond to $C_{3} S, C_{2} S, C_{3} A$, and $C_{4} F A$ were observed for all three samples, their intensities gradually decreased as the hydration proceeded. The progress of hydration was also confirmed by the appearance of new peaks identified as crystalline $\mathrm{Ca}(\mathrm{OH})_{2}$ for the two paste samples, the intensity of which increased with the hydration process. The paste samples also showed a distinct peak at a low Bragg angle around $9^{\circ}$, which may be attributed to C-S-H $[44,45]$.

(a)

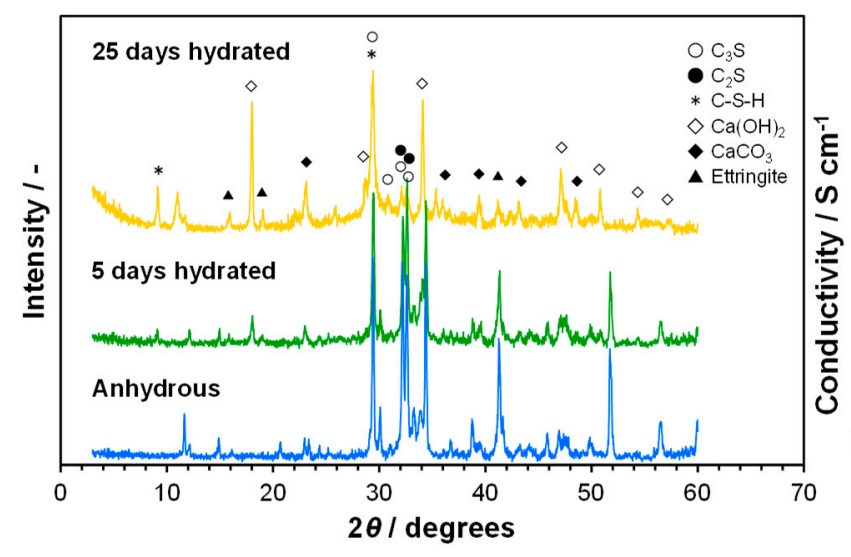

(b)

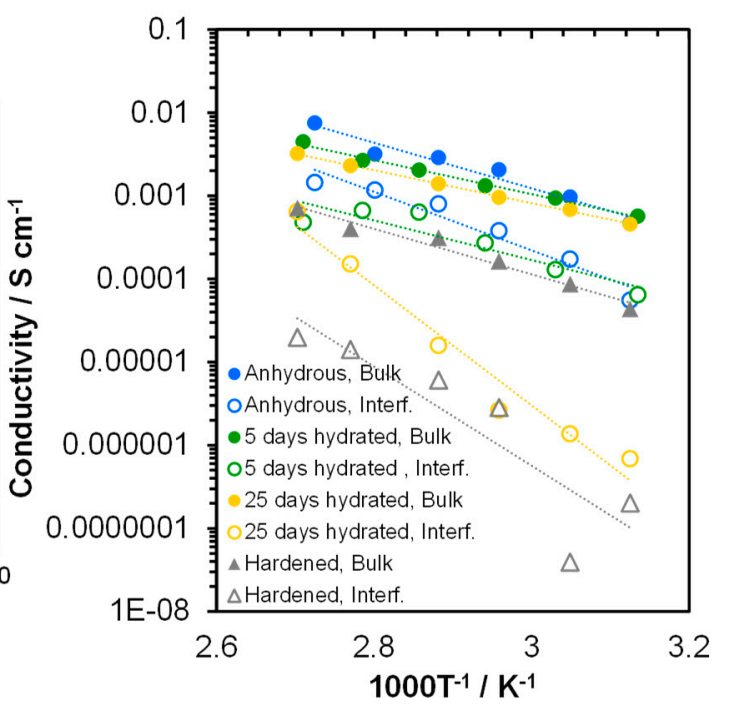

Figure 2. Characterization of the cement samples with different degrees of hydration. (a) XRD patterns.

(b) Temperature dependence of the bulk and interfacial conductivities.

The temperature dependence of the electrical conductivity for the three cement samples was measured over the temperature range of $50-100^{\circ} \mathrm{C}$, and the results are presented in Figure $2 \mathrm{~b}$. The bulk and interfacial conductivities were calculated using the following equation:

$$
\sigma_{\text {Bulk or Interf }}=t /\left(R_{\text {Bulk or Interf }} \times S\right) \text {, }
$$

where $\sigma_{\text {Bulk }}, \sigma_{\text {Interf }}, R_{\text {Bulk, }}$ and $R_{\text {Interf }}$ denote the conductivities and resistances of the bulk and grain boundary or pore wall phase of the sample, respectively, $t$ is the thickness of the sample, and $S$ is the surface area of electrode. Despite the different degrees of hydration, the three cement samples showed similar bulk conductivities at each temperature, so that their activation energies for ionic conduction were estimated to be $0.39-0.54 \mathrm{eV}$. In contrast, the interfacial conductivity was dependent on the sample species: anhydrous cement particles $(0.70 \mathrm{eV})=$ cement paste hydrated for 5 days $(0.66 \mathrm{eV})>$ cement paste hydrated for 25 days $(1.53 \mathrm{eV}$, hereafter denoted as highly hydrated sample). This difference was closely related to structural defects rather than the particle size of the samples, as shown in Figure 3, which indicated that the particle sizes of the three samples were comparable across the samples, while cracks were grown, especially in the highly hydrated sample. Similar low interfacial conductivities were observed for the hardened hydrated cement paste sample, in which a number of micrometer size holes were present. Structural defects, such as cracks and holes, intercept long-range ion transport, which results in low interfacial conductivity. Alternatively, the conduction pathway shifts from the grain boundaries of $\mathrm{C}_{3} \mathrm{~S}$ and $\mathrm{C}_{2} \mathrm{~S}$ particles to the pore walls of meso- or microporous $\mathrm{C}-\mathrm{S}-\mathrm{H}$ as a consequence of a significant hydration process. 

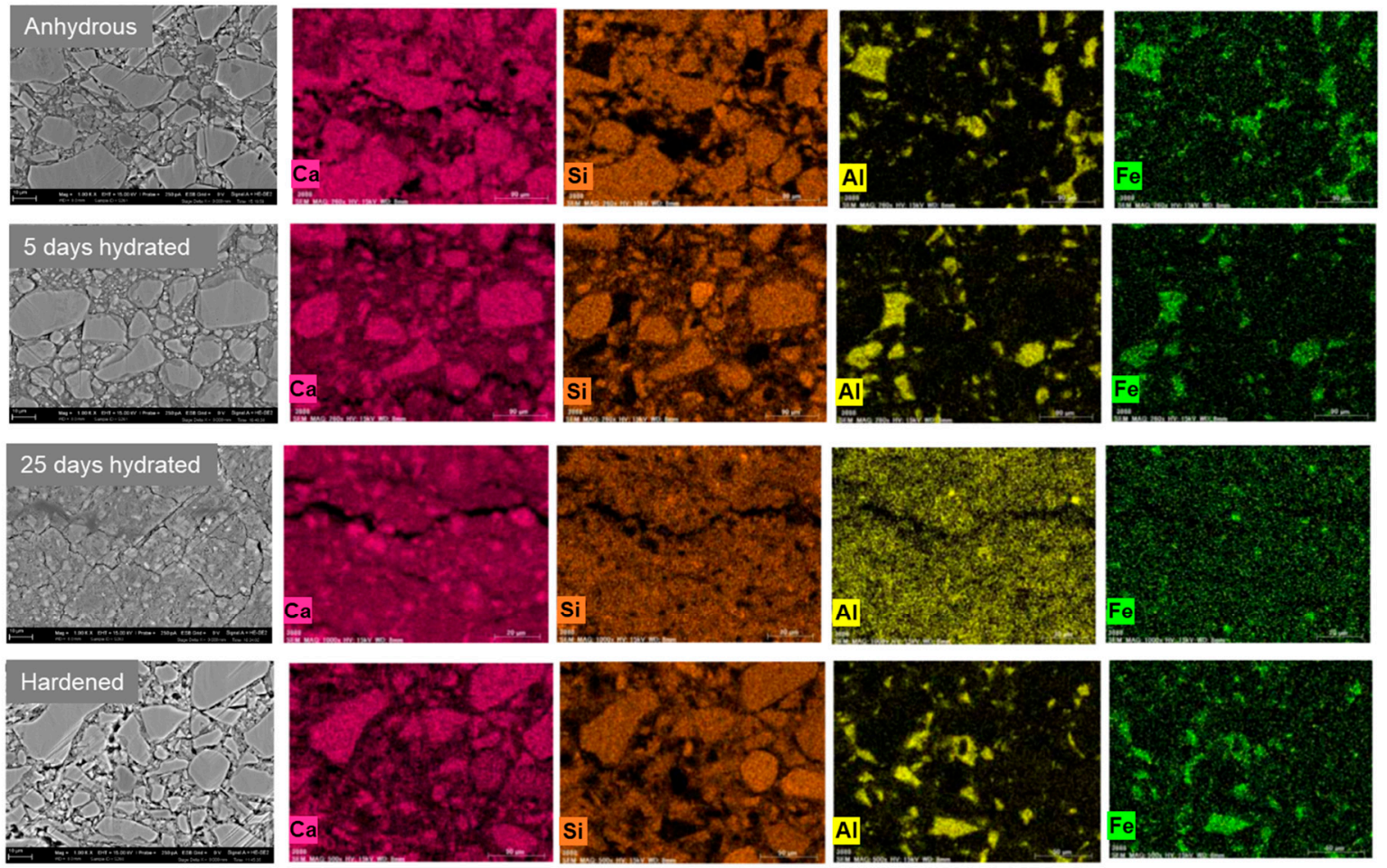

$\overline{10} \mu \mathrm{m}$

Figure 3. SEM images and energy dispersive $\mathrm{X}$-ray (EDX) elemental maps for $\mathrm{Ca}, \mathrm{Si}, \mathrm{Al}$, and $\mathrm{Fe}$ on the cross section of anhydrous, 5 days and 25 days hydrated, and hardened hydrated cement samples.

No significant difference was observed between the bulk conductivities of the anhydrous and hydrated cement samples, which suggests that crystalline $\mathrm{Ca}(\mathrm{OH})_{2}$ does not contribute to ionic conduction in the bulk of the three samples. Evidence for this suggestion is provided as follows. Water mist was sprayed onto the highly hydrated sample to obtain a W/C of 3:17. The XRD pattern and temperature dependence of the conductivity for this sample are shown in Figure 4a,b, respectively, along with data for the same sample with different pretreatments. The intensities of the XRD peaks attributed to $\mathrm{Ca}(\mathrm{OH})_{2}$ were found to be considerably decreased for the water-added sample. This sample showed much higher bulk and interfacial conductivities with much lower activation energies of ca. $0.1 \mathrm{eV}$, compared to those of the untreated sample, over the temperature range of $50-100{ }^{\circ} \mathrm{C}$. These results demonstrate that the dissolved $\mathrm{Ca}(\mathrm{OH})_{2}$ and the added water enhanced ionic conduction in the highly hydrated sample. In particular, the residual water was effective for improving the interfacial conductivity, which was achieved by the expansion of water channels on the particle surface or the pore walls. This may also transfer the vehicular diffusion mechanism to the Grotthuss mechanism [41-43]. This sample was subsequently dried in the container with sodium hydroxide, followed by XRD and conductivity measurements. As a consequence, the dissolved $\mathrm{Ca}(\mathrm{OH})_{2}$ was recrystallized, and both the bulk and interfacial conductivities were decreased. Based on these observations, crystalline $\mathrm{Ca}(\mathrm{OH})_{2}$ must be dissolved in excess water to be used as the source of charge carriers, the condition of which corresponds to the supersaturation of water vapor (relative humidity $>100 \%$ ). While it is difficult for gas-phase systems to sustain such a condition over the long term, this problem can be avoided in aqueous-phase systems (e.g., fuel cells that use hydrazine and sodium borohydride in alkaline solutions as the fuel) [46]. Subsequent trials were conducted using the anhydrous cement sample at a relative humidity of $100 \%$ and $70^{\circ} \mathrm{C}$. 
(a)

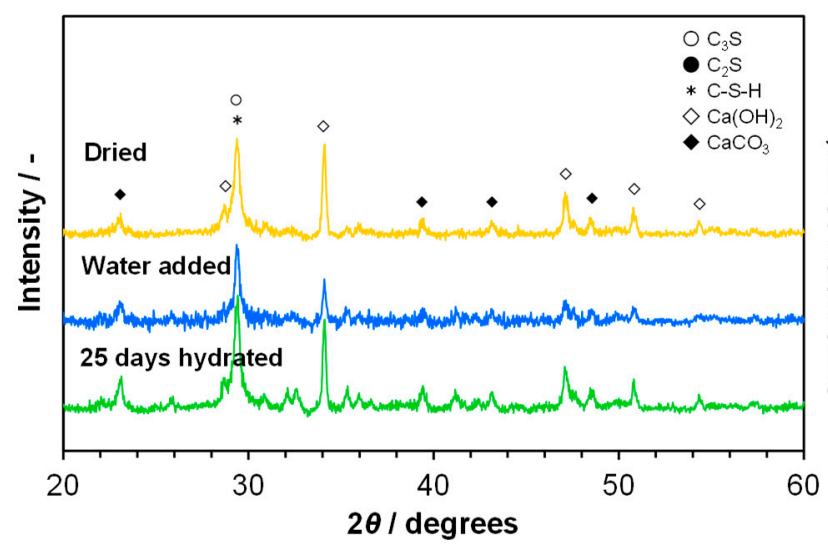

(b)

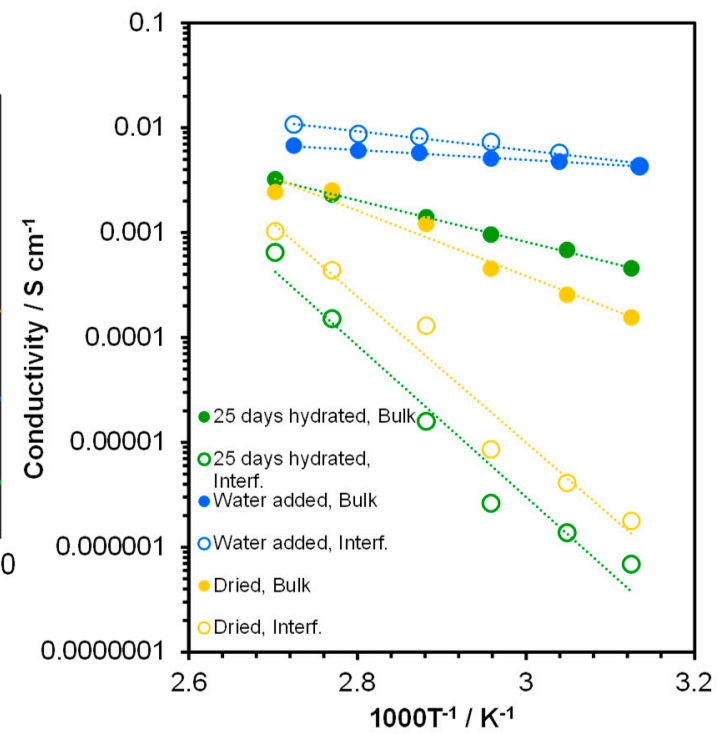

Figure 4. Characterization of the highly hydrated sample before and after addition of $15 \%$ water, and after drying. (a) XRD patterns. (b) Temperature dependence of the bulk and interfacial conductivities.

\subsection{Ionic Conducting Characteristics of Portland Cement}

In the ionic conduction model described in the previous section, not only $\mathrm{OH}^{-}$ions, but also metal $\left(\mathrm{Ca}^{2+}, \mathrm{Na}^{+}\right.$, or $\left.\mathrm{K}^{+}\right)$ions are possible charge carriers. A series of trials were made to determine the essential charge carrier in the cement sample. The cement sample was galvanostatically polarized with a current density of $0.4 \mathrm{~mA} \mathrm{~cm}{ }^{-2}$ in humidified air for $60 \mathrm{~h}$. Assuming that $\mathrm{Ca}^{2+}$ or $\mathrm{Na}^{+}\left(\right.$or K $\left.\mathrm{K}^{+}\right)$ ions are the charge carrier in the sample, the mole number of metal migrated from the anode to the cathode over $60 \mathrm{~h}$ was calculated to be $2.2 \times 10^{-4}$ moles for Ca or $4.4 \times 10^{-4}$ moles for Na according to Faraday's law. Thus, $8.97 \mathrm{mg}$ ( $25 \%$ of sample weight) of Ca or $10.3 \mathrm{mg}$ ( $29 \%$ of sample weight) of $\mathrm{Na}$ would be expected to be consumed at the anode and produced at the cathode. SEM images of the sample surfaces at the anode and cathode sides after polarization are presented in Figure 5, along with the corresponding EDX spectra. No significant difference in morphology was observed between the two surfaces. In addition, the magnitude of the EDX signal for $\mathrm{Ca}$ or $\mathrm{Na}$ at the cathode side was comparable to that at the anode side. Thus, the major charge carrier in the sample was determined to be $\mathrm{OH}^{-}$ions rather than $\mathrm{Ca}^{2+}$ or $\mathrm{Na}^{+}$ions, because both oxygen and water vapor, which are the source of $\mathrm{OH}^{-}$ions, are continuously supplied to the cathode. This postulation is supported by the appearance of XRD peaks for calcium carbonate $\left(\mathrm{CaCO}_{3}\right)$ at the anode side, which was in contrast to the appearance of XRD peaks for $\mathrm{Ca}(\mathrm{OH})_{2}$ at the cathode side (Figure 6). In the case of a hydroxide ion conductor, carbon corrosion occurs at the anode by polarization at high electrode potentials $[47,48]$, so that $\mathrm{Ca}(\mathrm{OH})_{2}$ reacts with $\mathrm{CO}_{2}$ produced according to Reaction (4) to form $\mathrm{CaCO}_{3}$.

$$
\text { Anode: } \mathrm{C} \text { (electrode) }+\mathrm{O}_{2} \text { (gas) } \rightarrow \mathrm{CO}_{2} \text { (gas). }
$$

Two types of galvanic cells, hydrogen and oxygen concentration cells (hereafter denoted as $\mathrm{H}_{2}$ and $\mathrm{O}_{2}$ cells, respectively), were fabricated using the cement sample as the electrolyte, and measurements were conducted at $70^{\circ} \mathrm{C}$. The electromotive force $(\mathrm{EMF})$ values were recorded while varying the partial pressure of hydrogen $\left(P_{\mathrm{H} 2}\right)$ at the cathode in the $\mathrm{H}_{2}$ cell with $P_{\mathrm{H} 2}$ at the anode in the $\mathrm{H}_{2}$ cell kept constant and by varying the partial pressure of oxygen $\left(P_{\mathrm{O} 2}\right)$ at the anode in the $\mathrm{O}_{2}$ cell with $P_{\mathrm{O} 2}$ at the cathode in the $\mathrm{O}_{2}$ cell kept constant (see the Method section for $P_{\mathrm{H} 2 \mathrm{O}}$ at all electrodes). The theoretical EMF values $(E s)$ of the $\mathrm{H}_{2}$ and $\mathrm{O}_{2}$ cells were calculated according to the following equations [33,34]: 
$\mathrm{H}_{2}$ cell:

$P_{\mathrm{H} 2 \text { High }}, \mathrm{Pt} / \mathrm{C} \mid$ Cement sample $\mid \mathrm{Pt} / \mathrm{C}, P_{\mathrm{H} 2 \text { Low }}$,

$$
\begin{gathered}
\text { Anode: } \mathrm{H}_{2}+2 \mathrm{OH}^{-} \rightarrow 2 \mathrm{H}_{2} \mathrm{O}+2 \mathrm{e}^{-}, \\
\text {Cathode: } 2 \mathrm{H}_{2} \mathrm{O}+2 \mathrm{e}^{-} \rightarrow 2 \mathrm{OH}^{-}+\mathrm{H}_{2}, \\
\quad E=R T / 2 \mathrm{~F} \ln \left(P_{\mathrm{H} 2 \text { Low }} / P_{\mathrm{H} 2 \text { High }}\right) .
\end{gathered}
$$

$\mathrm{O}_{2}$ cell:

$P_{\mathrm{O} 2 \text { Low }}, \mathrm{Pt} / \mathrm{C} \mid$ Cement sample | Pt/C, $P_{\mathrm{O} 2 \text { High, }}$

$$
\begin{gathered}
\text { Anode: } 4 \mathrm{OH}^{-} \rightarrow 2 \mathrm{H}_{2} \mathrm{O}+\mathrm{O}_{2}+4 \mathrm{e}^{-}, \\
\text {Cathode: } 2 \mathrm{H}_{2} \mathrm{O}+\mathrm{O}_{2}+4 \mathrm{e}^{-} \rightarrow 4 \mathrm{OH}^{-}, \\
\quad E=R T / 4 F \ln \left(P_{\mathrm{O} 2 \mathrm{High}} / P_{\mathrm{O} 2 \text { Low }}\right),
\end{gathered}
$$

where $R, T$, and $F$ denote the molar gas constant, the absolute temperature, and Faraday's constant, respectively. However, it should be noted that since Equations (7) and (10) are also derived by assuming that metal ions are the charge carrier, the EMF is not necessarily generated by a certain specific ionic conduction. Figure 7 shows that the observed EMF values were almost in agreement with the theoretical values for both the $\mathrm{H}_{2}$ and $\mathrm{O}_{2}$ cells, which indicates that the total ion transport number of this sample was approximately 1 in both the oxidative and reductive atmospheres. Therefore, this sample did not exhibit p- or n-type semiconductivity under such conditions, which is very convenient for use in electrochemical applications [49].
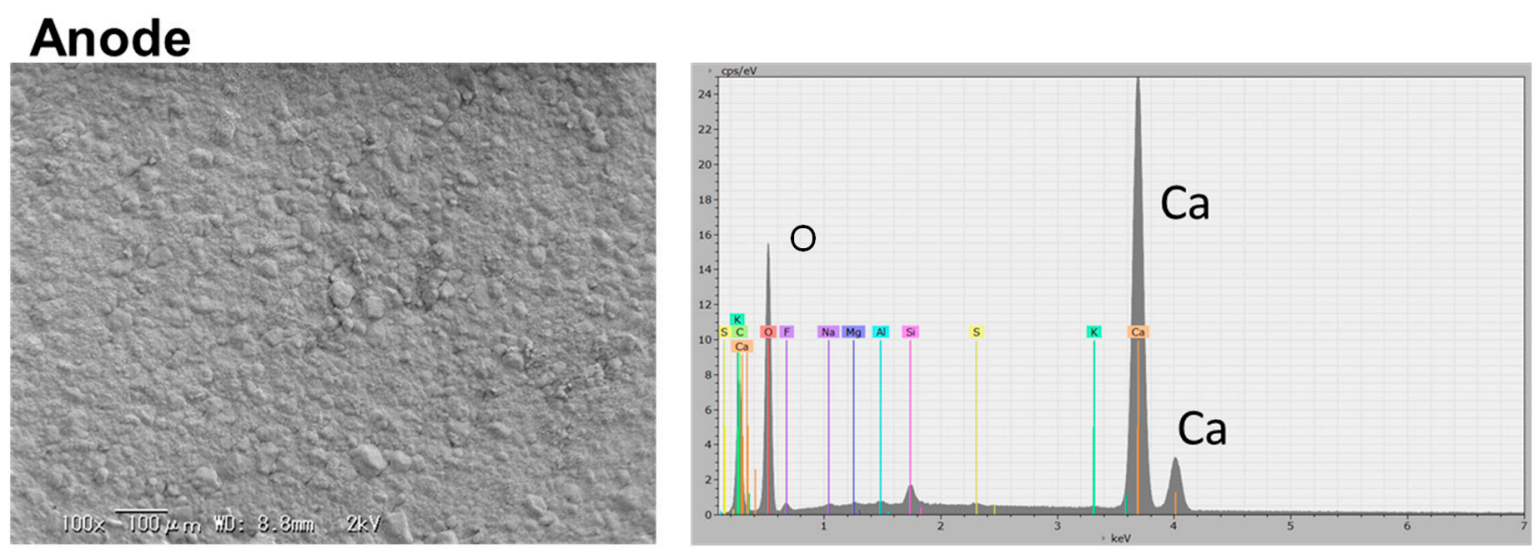

\section{Cathode}
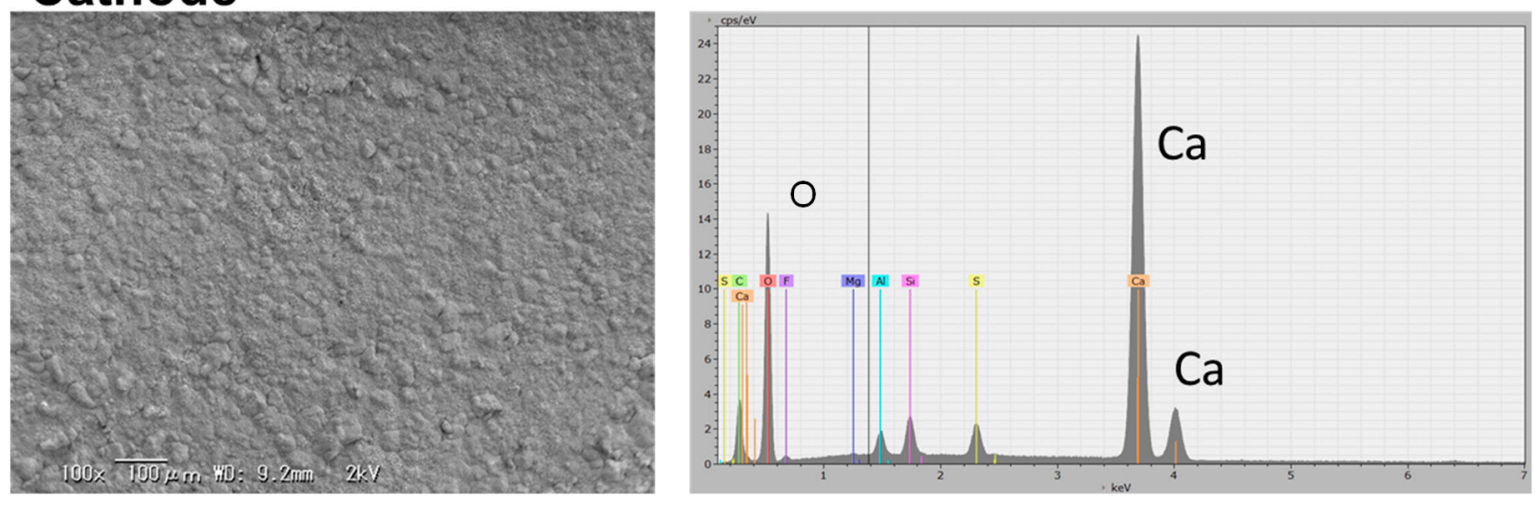

Figure 5. SEM images and EDX element analysis of the sample surfaces at the anode and cathode sides after cell polarization for $60 \mathrm{~h}$. Cell polarization was conducted in humidified air at $70{ }^{\circ} \mathrm{C}$. 


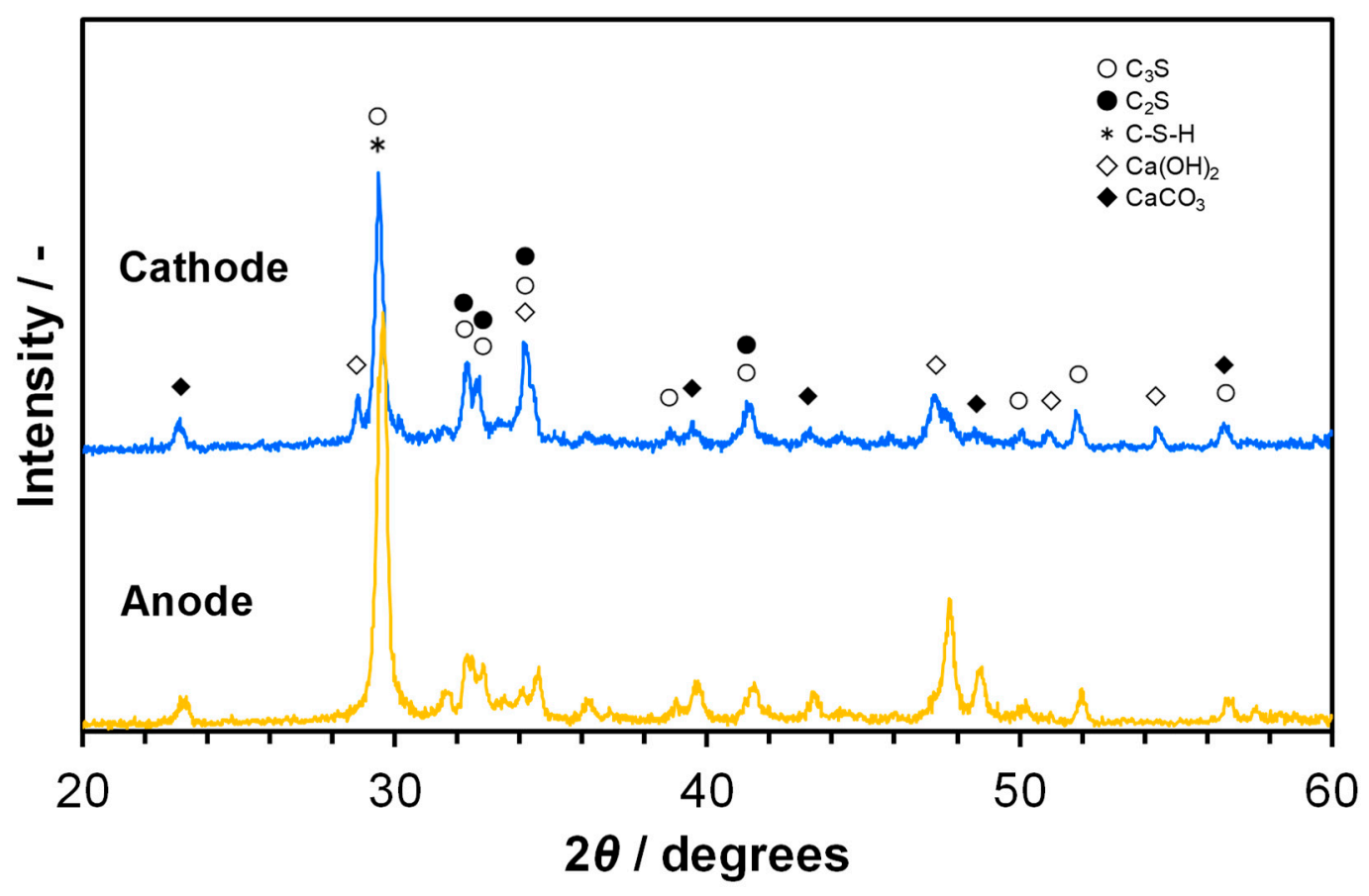

Figure 6. XRD profiles after polarization with a current density of $0.4 \mathrm{~mA} \mathrm{~cm}^{-2}$ in humidified air at $70{ }^{\circ} \mathrm{C}$ for $60 \mathrm{~h}$, followed by drying in a $\mathrm{CO}_{2}$-free container.

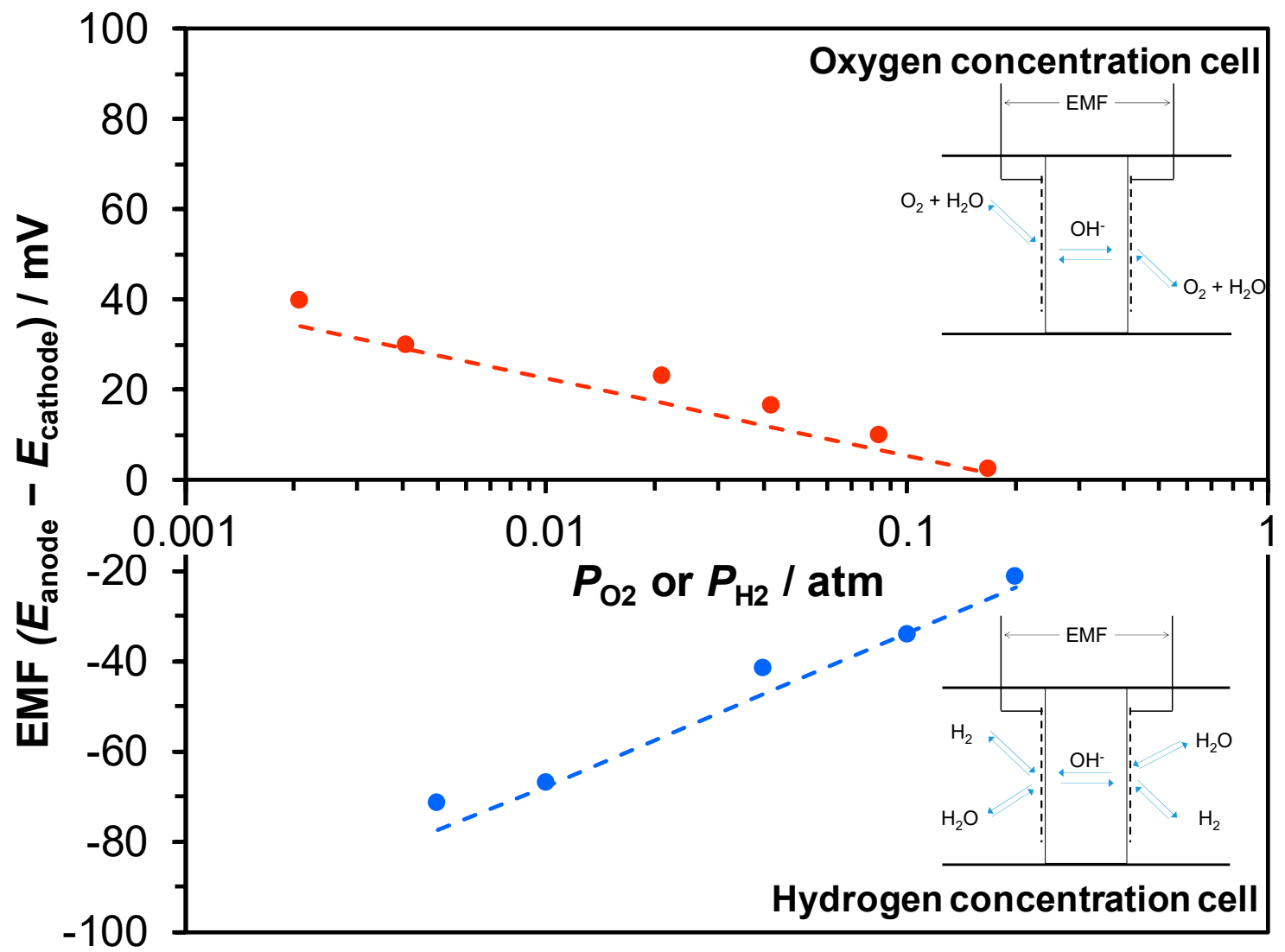

Figure 7. Electromotive forces (EMFs) generated from hydrogen and oxygen concentration cells at $70{ }^{\circ} \mathrm{C}$ as a function of $P_{\mathrm{H} 2}$ and $P_{\mathrm{O} 2}$, respectively. The dotted lines show the theoretical values for each gas concentration cell. 


\subsection{Degradation of Ionic Conduction in Cement by $\mathrm{CO}_{2}$ and Subsequent Amelioration}

Cement pastes have a high risk of having their chemical and mechanical characteristics altered in the presence of both $\mathrm{CO}_{2}$ and water [50,51]. $\mathrm{CO}_{2}$ is dissolved in water to form carbonic acid $\left(\mathrm{H}_{2} \mathrm{CO}_{3}\right)$, which penetrates into the cement, dissolving $\mathrm{Ca}(\mathrm{OH})_{2}$ into $\mathrm{Ca}^{2+}$ and $\mathrm{OH}^{-}$ions. $\mathrm{Ca}^{2+}$ ions and $\mathrm{OH}^{-}$ions easily react with hydrogen carbonate and $\mathrm{H}^{+}$to form $\mathrm{CaCO}_{3}$ and water, respectively. Similar carbonation can also occur for the present cement sample, because a small amount of $\mathrm{Ca}(\mathrm{OH})_{2}$ was produced through Reactions (1) and (2) under humidified conditions. The impedance spectra were measured in a humidified Ar flow containing $0.5 \% \mathrm{CO}_{2}$. Figure 8 a shows a significant decrease in the bulk and interfacial conductivities with the $\mathrm{CO}_{2}$ exposure time, the effect of which was larger for the interface than for the bulk. An XRD pattern was obtained after exposure to $\mathrm{CO}_{2}$ and subsequent drying. As shown in Figure 8b, the formation of $\mathrm{CaCO}_{3}$ was confirmed, and the peak intensities for $\mathrm{C}_{3} S$ and $C_{2} S$ were decreased, which is due to the dissolution of parts of these components in the carbonic acid. These results demonstrate a decrease in the amount of $\mathrm{OH}^{-}$ions, which reduce both the bulk and interfacial conductivities. In addition, $\mathrm{CaCO}_{3}$ precipitates on the surface of $\mathrm{C}_{3} \mathrm{~S}$ and $\mathrm{C}_{2} \mathrm{~S}$ particles or on the pore wall of C-S-H products, which further reduces the interfacial conductivity.

(a)

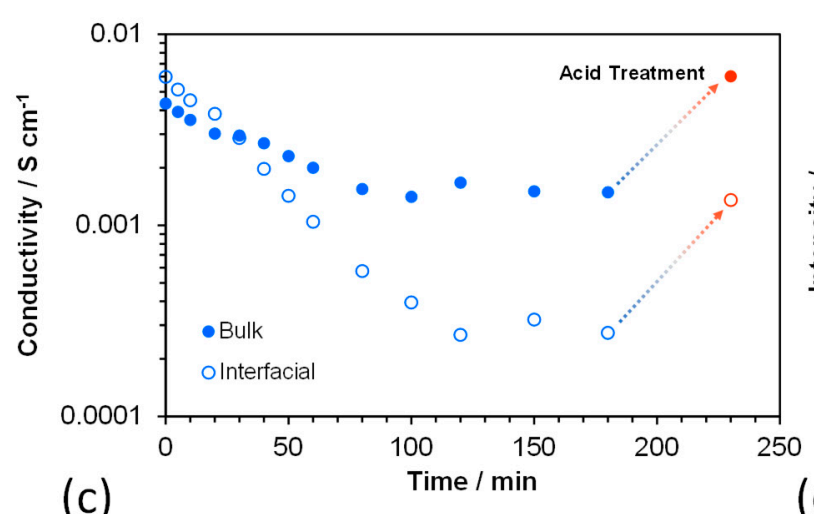

(c)

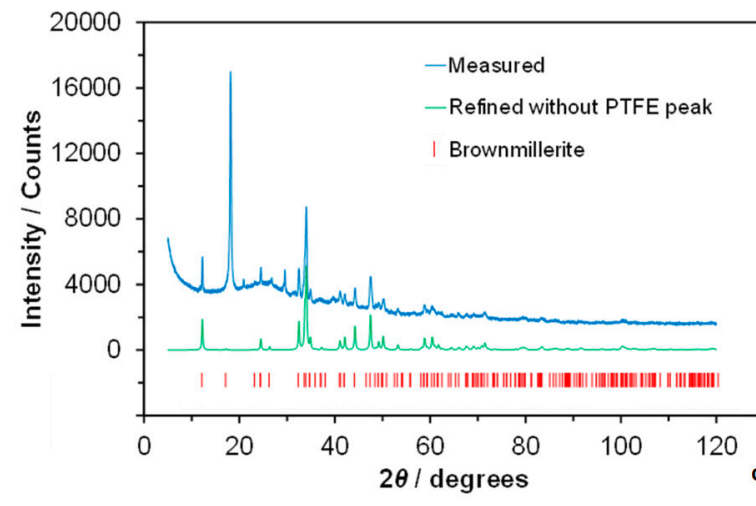

(b)

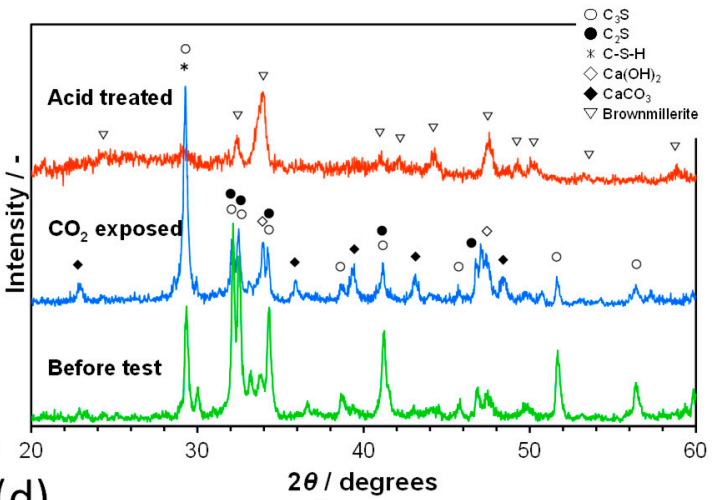

(d) 
of $18 \%$ is not an optimized value). A large amount of fine bubbles were formed from the sample surface in the solution. After bubble formation was completed, the sample was thoroughly washed with deionized water and then dried in the drying container. As a result of the acid treatment, the bulk conductivity returned to the initial value or greater, while the interfacial conductivity was improved to $17 \%$ of the initial value (Figure 8a). The XRD peaks of $\mathrm{CaCO}_{3}$ disappeared along with those of $\mathrm{C}_{3} \mathrm{~S}$, $\mathrm{C}_{2} \mathrm{~S}$, and $\mathrm{C}_{3} \mathrm{~A}$, while those of $\mathrm{C}_{4} \mathrm{AF}$ remained after the acid treatment (Figure 8b). The Rietveld analysis (Figure 8c) revealed that the octahedral and tetrahedral layers were alternately connected in the $\mathrm{C}_{4} \mathrm{AF}$ structure to form a three-dimensional framework with the $\mathrm{Ca}^{2+}$ ions in interstitial voids (space group $\operatorname{Ibm} 2, \mathrm{a}=5.5283(5) \AA, \mathrm{b}=14.573(1) \AA$, and $\mathrm{c}=5.3272(5) \AA$ ), as shown in Figure 8d. Ectors et al. recently proposed new reaction steps for the $\mathrm{C}_{4} \mathrm{AF}$ hydration process, which is accompanied by the production of $\mathrm{Ca}(\mathrm{OH})_{2}$ [6]. Thus, it is possible that similar to $\mathrm{C}_{3} \mathrm{~S}$ and $\mathrm{C}_{2} \mathrm{~S}, \mathrm{C}_{4} \mathrm{AF}$ provides conductive $\mathrm{OH}^{-}$ions to the sample through Reactions (1) and (2), which returns the bulk conductivity to the initial value. On the other hand, since $\mathrm{Na}_{2} \mathrm{O}$ and $\mathrm{K}_{2} \mathrm{O}$ are most likely washed away with deionized water in the acid treatment, the contribution of these metal ions to the bulk conductivity is negligible under the present conditions. A possible reason for the interfacial conductivity being lower than the initial value is that insulating materials are formed at the interface between the $\mathrm{C}_{4} \mathrm{AF}$ particles by the acid treatment; the XRD pattern of the sample after acid treatment and drying had an elevated background in the range $20-40^{\circ}$ (Figure 8b), which indicates a non-negligible amount of amorphous materials [54]. Therefore, this technique should be further optimized by precise control of the amount of acid or the treatment time.

\section{Conclusions}

Ionic conduction in anhydrous cement particles and hydrated cement pastes was investigated by preparing a $300 \mu \mathrm{m}$ thick membrane sample, followed by EIS measurements in an atmosphere saturated with water vapor (relative humidity $=100 \%$ ) at various temperatures $\left(50-100{ }^{\circ} \mathrm{C}\right.$ ). The ionic conductivity consisted of bulk and interfacial components, distinguished by the ion transport that corresponds to the frequency and dependent on the structural factors or not. Both the conductivity components were enhanced by an increase in the $P_{\mathrm{H} 2 \mathrm{O}}$ and temperature, the effects of which were attributed to the reaction of $\mathrm{CaO}$ in the $\mathrm{C}_{3} \mathrm{~S}$ and water vapor at high $P_{\mathrm{H} 2 \mathrm{O}}$ and to the acceleration of this reaction at high temperature, respectively. An additional effect was obtained by the formation of ion channels arising from the aggregated water molecules through the cement. Crystalline $\mathrm{Ca}(\mathrm{OH})_{2}$ was not necessarily required for ionic conduction in the cement, thus allowing for the use of anhydrous cement particles as an ionic conductor. $\mathrm{OH}^{-}$ions functioned as the charge carrier in the cement, and no change in structure or composition by long-term polarization of the sample was observed. Other charge carriers, such as $\mathrm{Ca}^{2+}, \mathrm{Na}^{+}$, and $\mathrm{K}^{+}$ions, electrons, and electron holes, were excluded, at least under the present conditions. Similar to conventional hydroxide ionic conductors, the cement suffered from a degradation of ionic conduction in the presence of $\mathrm{CO}_{2}$ and water vapor through the dissolution of $\mathrm{CO}_{2}$ in water, and the subsequent formation of $\mathrm{CaCO}_{3}$. The lowered bulk and interfacial conductivities were recovered to some extent by a decarbonation reaction in acetic acid solution at room temperature.

Author Contributions: Conceptualization, T.H. (Takashi Hibino); methodology, M.N. and T.H. (Takashi Hibino); investigation, K.K., T.H. (Tetsuya Hori) and Y.L.; data analysis, all authors; writing - original draft preparation, T.H. (Takashi Hibino); writing - review and editing, M.N.; supervision, T.H. (Takashi Hibino); funding acquisition, M.N. and T.H. (Takashi Hibino).

Funding: This research was funded by a Kakenhi Grant-in-Aid (Nos. 17H01895 and 17K14834) from the Japan Society for the Promotion of Science (JSPS), and by a grant (No. JPMJCR18R2) from the CREST program of the Japan Science and Technology Agency (JST).

Acknowledgments: The authors would like to thank Hikaru Nakamura, Ippei Maruyama, and Yoshikazu Araki (Nagoya University) for inspiring the present work.

Conflicts of Interest: The authors declare no conflict of interest. 


\section{References}

1. Beaudoin, J.J.; Ramachandran, V.S. A new perspective on the hydration characteristics of cement phases. Cem. Concr. Res. 1992, 22, 689-694. [CrossRef]

2. Chen, Y.; Odler, I. On the origin of portland cement setting. Cem. Concr. Res. 1992, 22, 1130-1140. [CrossRef]

3. Zanni, H.; Rassem-Bertolo, R.; Masse, S.; Fernandez, L.; Nieto, P.; Bresson, B. A spectroscopic NMR investigation of the calcium silicate hydrates present in cement and concrete. Magn. Reson. Imaging 1996, 14, 827-831. [CrossRef]

4. Grutzeck, M.W. A new model for the formation of calcium silicate hydrate (C-S-H). Mater. Res. Innov. 1999, 3, 160-170. [CrossRef]

5. Ménétrier, D.; Jawed, I.; Sun, T.S.; Skalny, J. Surface studies of hydrated $\beta-C_{2}$ S. Cem. Concr. Res. 1980, 10, 425-432. [CrossRef]

6. Ectors, D.; Neubauer, J.; Goetz-Neunhoeffer, F. The hydration of synthetic brownmillerite in presence of low Ca-sulfate content and calcite monitored by quantitative in-situ-XRD and heat flow calorimetry. Cem. Concr. Res. 2013, 54, 61-68. [CrossRef]

7. Matschei, T.; Lothenbach, B.; Glasser, F.P. Thermodynamic properties of Portland cement hydrates in the system $\mathrm{CaO}-\mathrm{Al}_{2} \mathrm{O}_{3}-\mathrm{SiO}_{2}-\mathrm{CaSO}_{4}-\mathrm{CaCO}_{3}-\mathrm{H}_{2} \mathrm{O}$. Cem. Concr. Res. 2007, 37, 1379-1410. [CrossRef]

8. Šavija, B.; Luković, M. Carbonation of cement paste: Understanding, challenges, and opportunities. Constr. Build. Mater. 2016, 117, 285-301. [CrossRef]

9. Ekolu, S.O. A review on effects of curing, sheltering, and $\mathrm{CO}_{2}$ concentration upon natural carbonation of concrete. Constr. Build. Mater. 2016, 127, 306-320. [CrossRef]

10. Richardson, I.G. The calcium silicate hydrates. Cem. Concr. Res. 2008, 38, 137-158. [CrossRef]

11. Puligilla, S.; Mondal, P. Co-existence of aluminosilicate and calcium silicate gel characterized through selective dissolution and FTIR spectral subtraction. Cem. Concr. Res. 2015, 70, 39-49. [CrossRef]

12. Fernández, A.; García Calvo, J.L.; Alonso, M.C. Ordinary Portland cement composition for the optimization of the synergies of supplementary cementitious materials of ternary binders in hydration processes. Cem. Concr. Compos. 2018, 89, 238-250. [CrossRef]

13. Hu, C.; Ruan, Y.; Yao, S.; Wang, F.; He, Y.; Gao, Y. Insight into the evolution of the elastic properties of calcium-silicate-hydrate (C-S-H) gel. Cem. Concr. Compos. 2019, 104. [CrossRef]

14. Saafi, M.; Gullane, A.; Huang, B.; Sadeghi, H.; Ye, J.; Sadeghi, F. Inherently multifunctional geopolymeric cementitious composite as electrical energy storage and self-sensing structural material. Compos. Struct. 2018, 201, 766-778. [CrossRef]

15. Cabeza, M.; Merino, P.; Miranda, A.; Nóvoa, X.R.; Sanchez, I. Impedance spectroscopy study of hardened Portland cement paste. Cem. Concr. Res. 2002, 32, 881-891. [CrossRef]

16. Coppio, G.J.L.; de Lima, M.G.; Lencioni, J.W.; Cividanes, L.S.; Dyer, P.P.O.L.; Silva, S.A. Surface electrical resistivity and compressive strength of concrete with the use of waste foundry sand as aggregate. Constr. Build. Mater. 2019, 212, 514-521. [CrossRef]

17. Dong, B.Q.; Qiu, Q.W.; Xiang, J.Q.; Huang, C.J.; Xing, F.; Han, N.X.; Lu, Y.Y. Electrochemical impedance measurement and modeling analysis of the carbonation behavior for cementititous materials. Constr. Build. Mater. 2014, 54, 558-565. [CrossRef]

18. Neithalath, N.; Jain, J. Relating rapid chloride transport parameters of concretes to microstructural features extracted from electrical impedance. Cem. Concr. Res. 2010, 40, 1041-1051. [CrossRef]

19. Xing, L.; Das, P.K.; Song, X.; Mamlouk, M.; Scott, K. Numerical analysis of the optimum membrane/ionomer water content of PEMFCs: The interaction of Nafion ${ }^{\circledR}$ ionomer content and cathode relative humidity. Appl. Energy 2015, 138, 242-257. [CrossRef]

20. Liu, L.; Chen, W.; Li, Y. An overview of the proton conductivity of nafion membranes through a statistical analysis. J. Membr. Sci. 2016, 504, 1-9. [CrossRef]

21. Heo, P.; Shibata, H.; Nagao, M.; Hibino, T.; Sano, M. Performance of an intermediate-temperature fuel cell using a proton-conducting $\mathrm{Sn}_{0.9} \mathrm{In}_{0.1} \mathrm{P}_{2} \mathrm{O}_{7}$ electrolyte. J. Electrochem. Soc. 2006, 153, A897-A901. [CrossRef]

22. Li, Q.; He, R.; Jensen, J.O.; Bjerrum, N.J. Approaches and recent development of polymer electrolyte membranes for fuel cells operating above $100{ }^{\circ} \mathrm{C}$. Chem. Mater. 2003, 15, 4896-4915. [CrossRef]

23. Haile, S.M.; Chisholm, C.R.I.; Sasaki, K.; Boysen, D.A.; Uda, T. Solid acid proton conductors: From laboratory curiosities to fuel cell electrolytes. Faraday Discuss. 2007, 134, 17-39. [CrossRef] 
24. Xiong, Y.; Fang, J.; Zeng, Q.H.; Liu, Q.L. Preparation and characterization of cross-linked quaternized poly (vinyl alcohol) membranes for anion exchange membrane fuel cells. J. Membr. Sci. 2008, 311, 319-325. [CrossRef]

25. Antolini, E.; Gonzalez, E.R. Alkaline direct alcohol fuel cells. J. Power Sources 2010, 195, 3431-3450. [CrossRef]

26. Leng, Y.; Chen, G.; Mendoza, A.J.; Tighe, T.B.; Hickner, M.A.; Wang, C.-Y. Solid-state water electrolysis with an alkaline membrane. J. Am. Chem. Soc. 2012, 134, 9054-9057. [CrossRef]

27. Arges, C.G.; Parrondo, J.; Johnson, G.; Nadhan, A.; Ramani, V. Assessing the influence of different cation chemistries on ionic conductivity and alkaline stability of anion exchange membranes. J. Mater. Chem. 2012, 22, 3733-3744. [CrossRef]

28. Wang, W.; Wang, S.; Xie, X.; Lv, Y.; Ramani, V.K. Hydroxide-ion induced degradation pathway for dimethylimidazolium groups in anion exchange membranes. J. Membr. Sci. 2014, 462, 112-118. [CrossRef]

29. Chempath, S.; Einsla, B.R.; Pratt, L.R.; Macomber, C.S.; Boncella, J.M.; Rau, J.A.; Pivovar, B.S. Mechanism of tetraalkylammonium headgroup degradation in alkaline fuel cell membranes. J. Phys. Chem. C 2008, 112, 3179-3182. [CrossRef]

30. Zhang, H.; Shen, P.K. Recent development of polymer electrolyte membranes for fuel cells. Chem. Rev. 2012, 112, 2780-2832. [CrossRef]

31. Chindaprasirt, P.; Hatanaka, S.; Chareerat, T.; Mishima, N.; Yuasa, Y. Cement paste characteristics and porous concrete properties. Constr. Build. Mater. 2008, 22, 894-901. [CrossRef]

32. Tikkanen, J.; Cwirzen, A.; Penttala, V. Effects of mineral powders on hydration process and hydration products in normal strength concrete. Constr. Build. Mater. 2014, 72, 7-14. [CrossRef]

33. Nagao, M.; Kamiya, T.; Heo, P.; Hibino, T.; Sano, M.; Tomita, A. Proton conduction in $\mathrm{In}^{3+}$-doped $\mathrm{SnP}_{2} \mathrm{O}_{7}$ at intermediate temperatures. J. Electrochem. Soc. 2006, 153, A1604-A1609. [CrossRef]

34. Shi, R.; Liu, J.; Wang, H.; Wu, F.; Miao, H. Intermediate temperature fuel cell durability of Eu-doped $\mathrm{SrCeO}_{3}-\mathrm{SrZrO}_{3}$ solid solution/ NaCl-KCl composite electrolyte. Ceram. Int. 2017, 43, 16931-16935. [CrossRef]

35. Capaccioli, S.; Lucchesi, M.; Casalini, R.; Rolla, P.A.; Bona, N. Effect of water inclusions on charge transport and polarization in porous media. IEEE Trans. Dielectr. Electr. Insul. 2001, 8, 454-460. [CrossRef]

36. Das, A.; Thakur, A.K.; Kumar, K. Evidence of low temperature relaxation and hopping in ion conducting polymer blend. Solid State Ion. 2014, 262, 815-820. [CrossRef]

37. Bi, L.; Fabbri, E.; Sun, Z.; Traversa, E. Sinteractive anodic powders improve densification and electrochemical properties of $\mathrm{BaZr}_{0.8} \mathrm{Y}_{0.2} \mathrm{O}_{3-\delta}$ electrolyte films for anode-supported solid oxide fuel cells. Energy Environ. Sci. 2011, 4, 1352-1357. [CrossRef]

38. Bui, P.T.; Ogawa, Y.; Nakarai, K.; Kawai, K.; Sato, R. Internal curing of Class-F fly-ash concrete using high-volume roof-tile waste aggregate. Mater. Struct. Constr. 2017, 50, 1-12. [CrossRef]

39. MacLaren, D.C.; White, M.A. Cement: Its chemistry and properties. J. Chem. Educ. 2003, 80, $623-635$. [CrossRef]

40. Korpa, A.; Kowald, T.; Trettin, R. Hydration behaviour, structure and morphology of hydration phases in advanced cement-based systems containing micro and nanoscale pozzolanic additives. Cem. Concr. Res. 2008, 38, 955-962. [CrossRef]

41. Grew, K.N.; Chiu, W.K.S. A dusty fluid model for predicting hydroxyl anion conductivity in alkaline anion exchange membranes. J. Electrochem. Soc. 2010, 157, B327-B337. [CrossRef]

42. Zhang, W.; Van Duin, A.C.T. ReaxFF reactive molecular dynamics simulation of functionalized poly (phenylene oxide) anion exchange membrane. J. Phys. Chem. C 2015, 119, 27727-27736. [CrossRef]

43. Huo, J.; Qi, W.; Zhu, H.; Yang, B.; He, G.; Bao, J.; Zhang, X.; Yan, X.; Gao, L.; Zhang, N. Molecular dynamics simulation on the effect of water uptake on hydrogen bond network for $\mathrm{OH}^{-}$conduction in imidazolium-g-PPO membrane. Int. J. Hydrogen Energy 2019, 44, 3760-3770. [CrossRef]

44. Pomiès, M.-P.; Lequeux, N.; Boch, P. Speciation of cadmium in cement. Cem. Concr. Res. 2001, 31, 563-569. [CrossRef]

45. Cong, X.; Kirkpatrick, R.J. ${ }^{29}$ Si MAS NMR study of the structure of calcium silicate hydrate. Adv. Cem. Based Mater. 2002, 3, 144-156. [CrossRef]

46. Ong, B.C.; Kamarudin, S.K.; Basri, S. Direct liquid fuel cells: A review. Int. J. Hydrogen Energy 2017, 42, 10142-10157. [CrossRef] 
47. Cao, Y.C.; Wang, X.; Mamlouk, M.; Scott, K. Preparation of alkaline anion exchange polymer membrane from methylated melamine grafted poly (vinylbenzyl chloride) and its fuel cell performance. J. Mater. Chem. 2011, 21, 12910-12916. [CrossRef]

48. Zeng, L.; Zhao, T.S.; An, L. A high-performance supportless silver nanowire catalyst for anion exchange membrane fuel cells. J. Mater. Chem. A 2015, 3, 1410-1416. [CrossRef]

49. Steele, B.C.H.; Heinzel, A. Materials for fuel-cell technologies. Nature 2001, 414, 345-352. [CrossRef]

50. Kutchko, B.G.; Strazisar, B.R.; Dzombak, D.A.; Lowry, G.V.; Thauiow, N. Degradation of well cement by $\mathrm{CO}_{2}$ under geologic sequestration conditions. Environ. Sci. Technol. 2007, 41, 4787-4792. [CrossRef]

51. Carroll, S.; Carey, J.W.; Dzombak, D.; Huerta, N.J.; Li, L.; Richard, T.; Um, W.; Walsh, S.D.C.; Zhang, L. Review: Role of chemistry, mechanics, and transport on well integrity in $\mathrm{CO}_{2}$ storage environments. Int. J. Greenh. Gas Control 2016, 49, 149-160. [CrossRef]

52. Naughton, M.S.; Brushett, F.R.; Kenis, P.J.A. Carbonate resilience of flowing electrolyte-based alkaline fuel cells. J. Power Sources 2011, 196, 1762-1768. [CrossRef]

53. Tewari, A.; Sambhy, V.; Urquidi MacDonald, M.; Sen, A. Quantification of carbon dioxide poisoning in air breathing alkaline fuel cells. J. Power Sources 2006, 153, 1-10. [CrossRef]

54. Mendes, A.; Gates, W.P.; Sanjayan, J.G.; Collins, F. NMR, XRD, IR and synchrotron NEXAFS spectroscopic studies of OPC and OPC/slag cement paste hydrates. Mater. Struct. Constr. 2011, 44, 1773-1791. [CrossRef]

(C) 2019 by the authors. Licensee MDPI, Basel, Switzerland. This article is an open access article distributed under the terms and conditions of the Creative Commons Attribution (CC BY) license (http://creativecommons.org/licenses/by/4.0/). 